TAPROBANICA, ISSN 1800-427X. April, 2009. Vol. 01, No. 01: pp. 1.

(C) Taprobanica Nature Conservation Society, 146, Kendalanda, Homagama, Sri Lanka.

\title{
AN INTRODUCTION TO TAPROBANICA
}

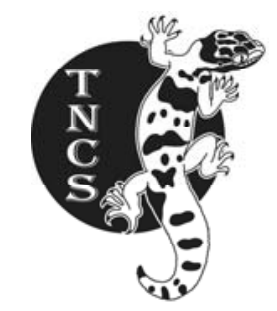

Greek astronomer Ptolemy compiled a map in the $2^{\text {nd }}$ century labeled the Island "Taprobane". Arab seafarers called it "Serendib". From the 1400s, Europeans identified that island as "Seylan", which was later anglicized to "Ceylon". In the 1500s Portugal and Spain established their dominance in the maritime trade of South and Southeast Asia. In the 1600s the Dutch emerged as the dominant colonial power in the region, followed in the 1700s by the British, then Independence Island after 1948 "Sri Lanka". The island is situated in the Indian Ocean, south west of the Indian peninsula, between $79^{\circ} 39^{\prime}$ ' and $81^{\circ} 53^{\prime}$ ' Eastern longitudes and $5^{\circ} 54^{\prime}$ and $9^{\circ} 52^{\prime}$ Northern latitudes, and has a total land area of $65,610 \mathrm{~km}^{2}$. "Taprobane" was a historical name for Sri Lanka and we use the name "Taprobanica" for our society as well as for our journal. Taprobanica Nature Conservation Society (TNCS) is an independent, non-governmental, nonprofit oriented voluntary organization dedicated to promote research, public awareness and nature conservation and it was established in 2007.

According to the present literature information on behaviors, feeding and breeding habits, population dynamics, ecology and threats are not properly understood for most of the species in Sri Lanka. Still a considerable number of species to be explored and the taxonomic status to be classified systematically. Therefore researches on the above aspects of Sri Lankan fauna are essential for the planning, implementation of proper "scientific conservation" and management programs which should be improved. Following the decline in the wake of independence from British in 1948, the past decade has seen an acceleration of the rate of the biodiversity exploration in Sri Lanka. While these works have been mostly of high quality, several papers has been published by local scientists unfamiliar with the science of taxonomy and the procedures of the International Code of Zoological Nomenclature (ICZN), resulting in the establishment of several unnecessary new names and invalid and erroneous information on Sri Lankan fauna. In such a situation, we have initiated publishing the Taprobanica, The Journal of South Asian Biodiversity largely in order to provide the opportunity to scientists on the natural history of Sri Lanka and Western Ghats to publish their results in a journal with reasonably high standards of production and review.

Taprobanica publishes original research papers, taxonomic descriptions, notes, observations, essays, opinions and short communications. The Taprobanica is published in one volume comprising two fascicles each year, starting with the first issue; volume 01 and number 01 in April 2009. The number of fascicles/supplements/special issues/occasional papers may be increased to six depending on the volume of contributions. Each fascicle of the journal will comprise 75-125 pages in perfect-bound double column format, printed on high quality mat paper. High quality colour and black \& white illustrations are encouraged, and will be accepted with no charge forpages and illustrations. The journal is expected to be circulated among leading conservation institutions and individuals in the field of ecology, biology and natural history.

The journal's geographic range extends to South Asia with special attention to Sri Lanka and Western Ghats biodiversity hotspot. We would like to provide space in equal parts to ecology, geology, biology, ethology, conservation breeding, conservation, evolution, morphology, physiology and systematics, but excludes techniques or sampling methods. This first issue deals mostly with Sri Lankan herpetofauna, because there is an increasing interest on herpetofauna than any other field in the subcontinent, which is one of the most populous biodiversity hotspots identified for conservation.

\section{A. A. Thasun Amarasinghe}

Managing Editor: Taprobanica, the journal of South Asian Biodiversity

April $06^{\text {th }}, 2009$ 